\title{
Encouraging innovative work behavior among college students through quality education to succeed the SDGs
}

\author{
Winarsih $^{1 *}$ and Arum Etikariena ${ }^{1}$ \\ ${ }^{1}$ Department of Industrial and Organizational Psychology, Faculty of Psychology, Universitas \\ Indonesia, Depok, 16424, Indonesia.
}

\begin{abstract}
Employee innovation plays an important role in organizational performance and survival, consequently, today's students are expected to be able to cultivate Innovative Work Behavior (IWB) before they become workers. This research aimed to investigate the correlation between one of the internal individual factors, namely proactive personality, and its relationship with IWB. This quantitative research was conducted on 539 undergraduate students at Universitas Indonesia, with ages ranging from 18-25 years. The students should at least in their second year of study. Proactive personality was measured using a scale developed by Bateman and Crant (1993). IWB was measured using a scale developed by Janssen (2000) with some modifications to ensure that the scale was suitable for college students. Pearson Product-moment Correlation is used to test the hypothesis. This study finds that there is a positive and significant relationship between proactive personality and IWB, $\mathrm{r}(539)=0,64, \mathrm{p}<$ 0,01 , one-tailed.
\end{abstract}

\section{Introduction}

At this time, organizations in Indonesia are facing the fourth industrial revolution [1]. This makes innovation becomes one of the crucial things to achieve organizational sustainability and to make the organization remain agile in dealing with the ever-changing business needs [2-3]. Thus, it is vital to prepare the workers to engage in Innovative Work Behavior (IWB), yet developing innovative capability in individuals is not easy to do in a short amount of time [4]. Even more, the development program provided by the organization will also require many resources that can be used to increase productivity amid fierce competition. A solution that can be considered for this case is to develop IWB among students before they become workers, such as at the tertiary and vocational education levels [5].

Unfortunately, the studies about IWB are mainly focusing on the worker populations and only a few in college students [6], especially in Indonesia. The context and the scale of the innovations in college and organization might be different indeed. Still, the authors

\footnotetext{
* Corresponding author: winatawinarsih@gmail.com
} 
argue that it would be better if students could foster IWB earlier to be better prepared when dealing with demands in the world of work [7]. The students are also assumed to have wider opportunities to learn and explore how to display IWB in college [8]. That is because the impacts of unsuccessful innovations (e.g., conflict with coworkers, stakeholders, individual reputation) [9-10] in college are considered less likely to occur since the scale of innovation carried out by students is still not as risky as in the organization. Therefore, the students can be empowered to be more innovative since in college.

The idea of developing IWB among students is in adherence with point 4.4 in Sustainable Development Goals (SDGs) about quality education, which stated: "By 2030, substantially increase the number of youth and adults who have relevant skills, including technical and vocational skills for employment, decent jobs, and entrepreneurship." [11]. As a part of the United Nations, Indonesia can show their commitment to support the SGDs by educating and developing IWB as one of the relevant skills in college students [12]. Then, the college students or the youth who later become well-prepared workers can be counted on to actively participate and be the driver to make the overall SGDs a success.

In connection to that matter, one of the efforts of the Indonesian Government related to innovation development can be seen from the Student Creativity Program (Program Kreativitas Mahasiswa/PKM) that was established by the Directorate General of Higher Education back in 2001. This program has the intention to foster, accommodate, and implement the creative and innovative ideas of the college students while bringing a positive impact to society and contributing to succeed the SDGs. Besides that, there is also National Student Science Week (Pekan Ilmiah Mahasiswa Nasional/PIMNAS) as an event for the students to present their PKM and compete with others from different universities [13]. In this study, the authors want to highlight the performance of Universitas Indonesia (UI) over the past nine years. Despite having the highest rank in Indonesia (based on the SGDs performance), UI's students only three times managed to occupy the top 10 positions, and not even once be the ultimate champion [14]. For that reason, authors expected that UI could improve their approach in providing education and developing IWB in their students to give a broader impact on the community.

There are variously internal and external factors as the antecedents of IWB, one of them is personality. Personality factors that have been found to be associated with IWB are the Big Five theory [3, 15], creative personality [15], need for achievement [3], proactive personality [16], and others. From these variables, the construct of personality that is considered most suitable in a situation full of changes is a proactive personality [17]. The relationship between proactive personality and IWB has been studied in diverse populations, such as employees in the company [16, 18-20], teachers [21-22], the millennial generation [23], entrepreneurs [24], but still not widely found in the student population. Therefore, this study wants to see whether proactive personality is also positively related to IWB in college students.

Individuals with relatively higher proactive personality levels can initiate and sustain their action that directly impacts the surrounding environment [25]. When facing uncomfortable or less ideal situations, they can recognize that there is a problem and will maximize the situation to do something. On the other hand, individuals with relatively low levels of proactive personality will exhibit opposing behaviors. They tend to be passive, accepting, adapting, and shaped from the existing environment [26]. Although the initial explanation about proactive personality implies a relatively stable trait or behavioral tendency [25], another perspective stated that personality remains possible to develop over time when supported with a favorable environment [27]. Hence, taking the personality development perspective might be more effective to sustain the behavior, IWB in this case, so that organizations can get long-term results [27]. 
In relation to IWB, individuals with relatively higher proactive personality levels will always seek solutions to problems and challenges that arise with innovations [19]. Individuals with these characteristics will more frequently express new ideas and are more motivated to ensure those ideas are implemented [16]. They can also persevere to bring a change despite being faced with obstacles [25]. Thus, individuals with relatively higher levels of proactive personality are expected to exhibit IWB more frequently.

\section{Method}

\subsection{Innovative work behavior (IWB)}

Innovative Work Behavior (IWB) is defined as "The intentional creation, introduction, and application of new ideas within a work role, group, or organization in order to benefit the role performance, group, or organization" [28]. There are three stages in IWB, that is idea generation, idea promotion, and idea realization. The first stage is when the individuals are aware of a problem, they notice something that is not properly fit, or when there are new trends or changes in their life. This makes individuals generate a new and useful idea or solution, that can be absolutely new or can be a result of adoption [29]. At the next stage, the individuals need to introduce their idea or solution, gain support from friends, colleagues, or other parties who have the resources so that the idea or solution can be applied. In the third stage, individuals apply the idea or solution by making prototypes or models that can be felt or held by others, which can be implemented within the scope of a role, group, or organization. Each stage of this innovation process has different activities so that the process can occur sequentially, but they can also be involved in a combination of several stages at the same time [29-30].

\subsection{Proactive personality}

Proactive personality was introduced as a dispositional construct that distinguishes individuals, to what extent a person can act to influence their environment [25]. This construct was built upon the interactionist perspective by Bandura in 1977 and 1986 who describe that individuals can influence their environment [25]. Individuals with relatively higher levels of proactive personality have several characteristics such as they can start and maintain an action so that it can have an impact on their surroundings; they can recognize and actively look for opportunities; show initiative and can be a pioneer when solving problems. They also depend on themselves and are not restricted by the situational conditions [25-26].

At first, proactive personality is considered as a trait or behavioral tendency that is relatively stable [25]. However, there is also another perspective that implies some changes can occur in a trait over time [27] because individuals will interact continuously with the world, face social contexts, and experiencing developmental challenges that can affect their personality throughout their life [31]. In the context of proactive personality, this also supported by the theory of reciprocal determinism which explains that not only individuals who can influence the environment, but the environment can influence the individuals too since the relationship is reciprocal [32]. Therefore, individuals can develop a proactive personality to a higher level when they have an environment that can facilitate the development in a relatively long period [27]. This argument is also supported by some previous researches [33-34]. Although it still requires a lot of further research, those results can provide a theoretical base that proactive personalities can develop over time [26]. 


\subsection{The relationship between proactive personality and IWB}

Each person can act differently when faced with the same situation. Some people can overcome the problems and bring constructive change, but some only go with the flow [25]. This indicates that the availability of an opportunity does not necessarily make the individuals decide to display an IWB, because they have to respond or act on that opportunity first [35]. That is why individuals with relatively higher levels of proactive personality are considered to do IWB more often. First, at the idea generation stage, they are the type of people who will actively seek information and opportunities to improve something in their lives. When there is a problem or challenge that arises, they can grab that chance to find solutions by developing ideas and suggestions [19, 36]. It also should be noted that they depend on themselves to do something, they do not just passively wait for other people [25]. To make those ideas or solutions come true, individuals with relatively higher levels of proactive personalities are actively and more frequently expressing their ideas [16-17]. They can effectively promote the ideas and gather broad support from those around them [16], such as from friends and supervisors [17]. The efforts that have been carried out previously encourage them to implement these ideas or solutions within the scope of individuals, groups, or organizations. In their journey, they persist to bring change even when faced with some obstacles [25]. Therefore, the authors formulate a hypothesis that proactive personality is positively and significantly related to IWB.

\subsection{Design and participants}

This study used a quantitative approach to see the correlation between proactive personality and IWB in the college student population. The sample is from undergraduate students at UI who are at least in their second year of study. This criterion is applied because first-year students are considered to still experiencing a period of transition from high school to college, both academically, socially, and personally [37]. In this study, the authors used the convenience sampling method to select the participants.

\subsection{Instruments}

The authors used the scale that had been adopted in the previous study, which is the Innovative Work Behavior Scale from Janssen to measure IWB [28, 38]. The scale has 9 items and covers the 3 stages of IWB (idea generation, idea promotion, and idea realization). Since this scale usually used for workers, the research team modified some of the items to match the context of college student's life. The participants were given 6 answer choices using a Likert scale, with 1 (Never did) until 6 (Always do). The total score is obtained from the accumulation of all items' scores. In this study, the Cronbach's alpha for this scale is 0,89 .

To measure proactive personality, the authors used Bateman and Crant's 17-item Proactive Personality Scale (PPS) [25]. Several items on that scale had been modified in a previous study [39] that also aimed at college students at UI. The answers in this scale are also used a Likert scale, ranging from 1 (Strongly disagree) to 6 (Strongly agree) for favorable items, dan vice versa for unfavorable items. The total score is the accumulation of the score from each item. The Cronbach's alpha for this scale is 0,87 .

\subsection{Procedure}

The research team conducted a face-to-face readability test with some college students and then revised the scales in accordance with their feedback. After that, the team prepared an 
online questionnaire using Google Form to conduct a pilot study with two considerations. First, this study used a self-report approach to obtain data from the participant. To prevent a common method variance [40], authors made some procedural effort such as ensuring participant anonymity, providing an instruction "There is no right or wrong answer" at the beginning of the questionnaire, as well as combining the PPS with two other researcher's measurement that used the same Likert scale. Those items were automatically randomized when displayed to the participant. Second, even though the total of the PPS and IWB scale were only 26 items, the participants had to answer 84 items since this questionnaire consists of several measurements from other researchers in the team. Thus, authors added one instructed response item "For this item, please choose option number 6 (Strongly Agree)" to see which participant who was or was not attentive when filling the questionnaire [41]. The participants who chose the incorrect answers were eliminated in this study. This questionnaire and the research procedures have been approved by the Ethics Committee at the Faculty of Psychology Universitas Indonesia.

The total participant of the pilot study were 70 students $(44,3 \%$ from UI and $55,7 \%$ from non-UI students) since 7 participants were eliminated. The result of this pilot study showed that the Cronbach's alpha for IWB scale was 0,88 which made the scale considered reliable [42]. All items on this scale also had a good corrected item-total correlation score $(>0,2)[43]$. On the other hand, the Cronbach's alpha score for PPS was 0,75 but 5 items had low corrected item-total correlation scores $(<0,2)$. After reviewing the result, 4 out of 5 items turned out to be unfavorable sentences. Some researchers found that using unfavorable items in the questionnaire has a negative effect on the reliability and validity of the scale [44]. Therefore, the authors decided to revert those items to the real scale [25] and not the modification one [39]. Authors did a back-translation and qualitative readability test with the team for those 4 items. The other item was already favorable, so the wording was only modified to make it clearer without changing the overall meaning. After completing that revision, the authors conducted data collection from 21 March-17 April 2020 using social media. IBM SPSS version 24 software is used to analyze the data, utilizing the descriptive statistics for the demographic data, and Pearson Product-moment Correlation to see the relationship between proactive personality and IWB. At the end of the study, 20 random participants were selected to get a reward.

\section{Results and discussion}

After eliminating the participants who were not giving their consent (5 people) and who were incorrect in answering the instructed response item (106 people), the total number of college students at UI in this study was 539. The participants consist of females $(65.7 \%)$ and males $(34.3 \%)$ students with age ranging from $18-25$ years $(\mathrm{M}=20.42, \mathrm{SD}=1.13)$. Most of them live with their nuclear family $(67.5 \%)$ and currently in the 4 th semester $(35.8 \%)$. The three faculties with the highest number of participants are the Faculty of Engineering (16.1\%), Faculty of Math and Natural Science $(14.1 \%)$, as well as Faculty of Humanities $(10.9 \%)$. The majority of the participant $(89.2 \%)$ also participate at least in one extracurricular activity, either inside or outside the university. The detailed information can be found in Table 1 below. 
Table 1. Demographic Data (N=539).

\begin{tabular}{|c|c|c|c|}
\hline \multicolumn{2}{|c|}{ Categories } & Mean/Frequency & $\begin{array}{l}\text { Standard Deviation/ } \\
\text { Percentage }\end{array}$ \\
\hline \multicolumn{2}{|l|}{ Age (years) } & 20.42 & 1.13 \\
\hline \multirow{2}{*}{ Sex } & Females & 354 & 65.7 \\
\hline & Males & 185 & 34.3 \\
\hline \multirow{4}{*}{ Semester } & $4^{\text {th }}$ semester & 193 & 35.8 \\
\hline & $6^{\text {th }}$ semester & 154 & 28.6 \\
\hline & $8^{\text {th }}$ semester & 189 & 35.1 \\
\hline & $10^{\text {th }}$ semester & 3 & 0.6 \\
\hline \multirow{14}{*}{ Faculty Origin } & Pharmacy & 32 & 5.9 \\
\hline & Nursing & 25 & 4.6 \\
\hline & Medicine & 13 & 2.4 \\
\hline & Dentistry & 25 & 4.6 \\
\hline & Public Health & 27 & 5.0 \\
\hline & Computer Science & 26 & 4.8 \\
\hline & Math \& Natural Science & 76 & 14.1 \\
\hline & Engineering & 87 & 16.1 \\
\hline & Economics \& Business & 37 & 6.9 \\
\hline & Law & 19 & 3.5 \\
\hline & Administration & 16 & 3.0 \\
\hline & Humanities & 59 & 10.9 \\
\hline & Social \& Political Sciences & 44 & 8.2 \\
\hline & Psychology & 53 & 9.8 \\
\hline \multirow{4}{*}{ Residence } & With nuclear family & 364 & 67.5 \\
\hline & With extended family & 15 & 2.8 \\
\hline & With friend & 1 & 0.2 \\
\hline & $\begin{array}{l}\text { Independent (boarding } \\
\text { house/rented house/ } \\
\text { dormitory/apartment) }\end{array}$ & 159 & 29.5 \\
\hline \multirow{8}{*}{$\begin{array}{l}\text { Extracurricular } \\
\text { Activity }\end{array}$} & $\begin{array}{l}\text { Work/internship/part time/ } \\
\text { freelance }\end{array}$ & 28 & 2.9 \\
\hline & Entrepreneurship & 44 & 4.6 \\
\hline & Committee & 267 & 27.9 \\
\hline & Organization & 255 & 26.7 \\
\hline & Community & 97 & 10.1 \\
\hline & $\begin{array}{l}\text { Student Activity Units (art, } \\
\text { sport, spiritual) }\end{array}$ & 139 & 14.5 \\
\hline & Others & 23 & 2.4 \\
\hline & Not involved at all & 103 & 10.8 \\
\hline
\end{tabular}

The lowest and the highest score for the IWB variable are 9 and 54, with an average score of 36.38 ( $\mathrm{SD}=8.48)$. For proactive personality, the lowest and the highest score of the participants are 31 and 99, with 70.47 as the average score $(\mathrm{SD}=11.15)$. With Pearson Product-moment Correlation analysis, the authors found that proactive personality and IWB has a positive and significant correlation, $\mathrm{r}(539)=0.64, \mathrm{p}<0.01$, one-tailed. Thus, the hypothesis is accepted, and this relationship has a large effect size [45].

Furthermore, the authors also conducted some analyses for the demographic data. The authors used the independent sample t-test to compare the average scores between IWB with gender (male or female), residence (with nuclear/extended family or live independently/with a friend), and extracurricular activity (actively participating or not at all). One-way ANOVA is also used to analyze the average scores between IWB with age 
(ranging from 18-25 years), and the cluster of the faculties (health sciences, social and humanities, science and technology).

Table 2. Independent Sample t-test Analysis of IWB with Gender, Residence, and Participation in Extracurricular Activity ( $\mathrm{N}=539)$.

\begin{tabular}{|l|c|c|c|}
\hline \multirow{2}{*}{ Demographic Variables } & \multicolumn{3}{|c|}{ IWB } \\
\cline { 2 - 4 } & t values & df & Sig. (2-tailed) \\
\hline Gender & -1.02 & 537 & 0.31 \\
\hline Residence & 0.59 & 537 & 0.56 \\
\hline $\begin{array}{l}\text { Participation in } \\
\text { extracurricular activity }\end{array}$ & 2.05 & 537 & $0.04^{*}$ \\
\hline
\end{tabular}

$* \mathrm{p}<.05$

Table 3. One-way ANOVA Analysis of IWB with Age and Clusters of Faculties (N=539).

\begin{tabular}{|l|c|c|c|}
\hline \multirow{2}{*}{ Demographic Variables } & \multicolumn{3}{|c|}{ IWB } \\
\cline { 2 - 4 } & F values & df & Sig. (2-tailed) \\
\hline Age & 0.87 & 6 & 0.52 \\
\hline Cluster of the faculties & 2.92 & 2 & 0.06 \\
\hline
\end{tabular}

Based on the result above, the average scores of IWB in students who are currently or have been participated in extracurricular activity $(\mathrm{M}=36,74, \mathrm{SD}=8,39)$ is significantly higher than the students who are not active at all $(\mathrm{M}=34,84, \mathrm{SD}=8,71), \mathrm{t}(537)=2,05, \mathrm{p}=$ $0,04, r=0,01$. Other than that, authors do not find any significant average score differences between IWB with gender, residence, age, or cluster of the faculties.

Research on proactive personality and IWB has been carried out in various populations such as employees in the company, the millennials, entrepreneurs, and so on, but it is not widely found in the college student population. The results of this study indicate that there is a positive and significant relationship between those two variables, so it is consistent with the previous results. The effect size in this study $(r=0.64)$ is also more or less the same as in the previous studies that have the coefficients ranging from 0.31 to $0.58[16,20$, 24]. Thus, it appears that the effect size trend of this relationship is in the range of medium to large effects.

The finding in this study implies that higher education institutions can encourage more IWB development for their students. The students are expected to be accustomed to IWB since in college so that when become workers, they just need some adjustment to the scale and context of innovation that exists in the organization. Based on the result, proactive personality can be considered as a factor that can help the development of IWB. The relationship between proactive personality and IWB can be explained by the interactionist perspective that has been widely adopted in personality theory, that is individuals can shape their environment [32]. The emergence of the problems, scientific discoveries, technological enhancement, and other things that happen in a college setting can be used as an opportunity for students to do IWB. Every student can change their environment, but this research shows that an individual's personality plays a role in that student's decision, whether they will take the opportunity to innovate or leave it [35]. Students with relatively higher levels of proactive personalities can grab those opportunities because they have several characteristics, such as more active in finding opportunities, taking action, showing initiative, etc. They rely on themselves to change the environment, not just go with the flow with the existing conditions [25-26]. These characteristics then drive them to display IWB more often than the others. This study also reveals that involvement in extracurricular activities is the demographic variable that significantly differentiates the average score of IWB among college students. The authors found students who were actively participating in extracurricular activities had a higher average score of IWB than those who were not 
involved in any extracurricular activity. From this result, it seems that extracurricular activities have an adequate role in relation to IWB.

However, this research is inseparable from several limitations. First, the IWB distribution was found to be slightly skewed negative, when ideally the parametric analysis must follow the normality assumption. The authors made several preventive procedural efforts, yet social desirability might still arise in the self-report questionnaire [40]. Some researchers said that if a study has a large sample, a parametric analysis using not normally distributed data is considered not causing significant integrity issues [46]. But still, it would be better if future studies can meet the normality assumption. One of the suggestions is the data can be obtained from multiple sources to make it more objective [40]. Second, all participants in this study are from UI, so the result cannot be generalized to the college student population. Therefore, future studies are expected to increase the number and expand the sample to make it more representative. Moreover, future studies can examine the factors that can help the development of proactive personality in college students. Other factors such as demographic or situational factors that might have an influence on the relationship between proactive personality and IWB (e.g., innovation climate, work characteristics) can also be considered to broaden the knowledge about the dynamics of this relationship.

The authors hope that this result can encourage Universitas Indonesia and the other higher education institutions to optimally develop the IWB in students since the process can take a lot of time. Curriculum modifications, involvement in extracurricular activities (e.g., organization, competition, internship program), etc. should be encouraged to facilitate the students in doing IWB. To develop a proactive personality, the institutions also can provide strategic thinking class [34] or teachers can also adjust the workload given so that it is not too easy nor too hard [33]. This is intended so that students can optimally recognize the opportunities when facing a less comfortable situation, and then use it to make innovation, no matter how simple the idea is.

\section{Conclusion}

Research about proactive personality and IWB among college students is still not widely found since most of them are focusing on the organization and worker population. From this study, the authors found that college students with a higher level of proactive personality will often engage in IWB, which is aligned with the previous studies. Hence, in adherence to point 4.4 in SDGs, higher education institutions are expected to provide more opportunities for the youth to develop proactive personality and IWB, so they can prepare to become the next workers in this competitive industry. By doing this, Indonesia can participate in succeeding the SDGs. The authors hope that the youth and workers who are well-prepared eventually can drive the success of the overall SDGs in the future.

\section{Acknowledgements}

This research is funded by the Faculty of Psychology Universitas Indonesia through grant Hibah Riset Dasar. The authors express gratitude for support.

\section{References}

1. T. Adharsyah, Jangan Salah Pilih Kuliah, Ini Pekerjaan yang Tren di Era 4.0, CNBC Indonesia (2019) https://www.cnbcindonesia.com/news/20190321182918-4-

62193/jangan-salah-pilih-kuliah-ini-pekerjaan-yang-tren-di-era-40 
2. S. K. Parker and U. K. Bindl, Proactivity at work: A big picture perspective on a construct that matters, in Proactivity at Work: Making Things Happen in Organizations, U. K. Parker, S. K. \& Bindl, 1-20 (Routledge, New York, 2017)

3. M. Zennouche, J. Zhang, and W. B. Wang, Factors influencing innovation at individual, group and organisational levels: A content analysis, Int. J. Inf. Syst. Change Manag., 7, 23-42 (2014) https://doi.org/10.1504/IJISCM.2014.065052

4. X. Zhong and Z. Liu, Studies on creativity enhancement of contemporary college students, 3rd Int. Conf. Sci. Soc. Res. ICSSR (2014) https://doi.org/10.2991/icssr14.2014.148

5. A. Etikariena, Analisis efek mediasi identitas organisasi dan kesiapan karyawan untuk berinovasi pada hubungan antara memori organisasi dengan perilaku kerja inovatif, Universitas Indonesia (2017)

6. S. H. M. Roffeei, F. D. Yusop, and Y. Kamarulzaman, Determinants of innovation culture amongst higher education students., Tojet - Turkish Online J. Educ. Technol., 17, 37-50 (2018)

7. P. Martín, K. Potočnik, and A. B. Fras, Determinants of students' innovation in higher education, Stud. High. Educ., 42, 1229-1243 (2017)

https://doi.org/10.1080/03075079.2015.1087993

8. Y. Chen and Y. Yin, Research on mechanism of innovation climate in college on college student's innovative behavior the mediating effects of intrinsic incentives, $3 \mathrm{rd}$ Int. Conf. Arts, Des. Contemp. Educ. ICADCE, 144, 914-917 (2017) https://doi.org/10.2991/icadce-17.2017.225

9. O. Janssen, Innovative behaviour and job involvement at the price of conflict and less satisfactory relations with co-workers, J. Occup. Organ. Psychol., 76, 347-364 (2003) https://doi.org/10.1348/096317903769647210

10. S. C. Shiu, S. Y. Lin, and H. O. Chien, The relationship between learning motivation and innovative behavior in the university students: From the perspective of creative self-efficacy, Int. J. Arts Sci., 5, 33-38 (2012)

11. U. Nations, About Major Groups and other stakeholders. https://sustainabledevelopment.un.org/aboutmajorgroups.html.

12. U. Nations, The 17 Goals: History. https://sdgs.un.org/goals

13. D. Kemahasiswaan and D. J. P. dan Kemahasiswaan, Pedoman Program Kreativitas Mahasiswa (PKM) Tahun 2020 (Kementerian Pendidikan dan Kebudayaan, 2020)

14. W. Winarso, Pekan Ilmiah Mahasiswa Nasional (PIMNAS) (2020) http://kemahasiswaandikti.blogspot.com/2015/11/pekan-ilmiah-mahasiswa-nasionalpimnas.html

15. M. M. Hammond, N. L. Neff, J. L. Farr, A. R. Schwall, and X. Zhao, Predictors of individual-level innovation at Work: A meta-analysis, Psychol. Aesthetics, Creat. Arts, 5, 90-105 (2011) https://doi.org/10.1037/a0018556

16. E. Giebels, R. S. M. de Reuver, S. Rispens, and E. G. Ufkes, The critical roles of task conflict and job autonomy in the relationship between personalities and innovative employee behavior, J. Appl. Behav. Sci., 52, 320-341 (2016) https://doi.org/10.1177/0021886316648774

17. B. Fuller and L. E. Marler, Change driven by nature: A meta-analytic review of the proactive personality literature, J. Vocat. Behav., 75, 329-345 (2009) https://doi.org/10.1016/j.jvb.2009.05.008

18. I. F. N. Khasanah and F. Himam, Kepemimpinan transformasional kepribadian proaktif dan desain kerja sebagai prediktor perilaku kerja inovatif, Gadjah Mada J. Psychol., 4, 143 (2018) https://doi.org/10.22146/gamajop.46361

19. F. J. Pons, J. Ramos, and A. Ramos, Antecedent variables of innovation behaviors in organizations: Differences between men and women, Rev. Eur. Psychol. Appl., 66, 
117-126 (2016) https://doi.org/10.1016/j.erap.2016.04.004

20. R. Windiarsih and A. Etikariena, Hubungan antara kepribadian proaktif dan perilaku inovatif di BUMN X, J. Psikogenes., 5, 123-134 (2017)

21. I. Helmy and M. P. Pratama, Pengaruh proactive personality dan pemberdayaan psikologis terhadap perilaku inovatif melalui creative self efficacy, J. Pro Bisnis, 11, 14-21 (2018)

22. M. Li, Y. Liu, L. Liu, and Z. Wang, Proactive personality and innovative work behavior: The mediating effects of affective states and creative self-efficacy in teachers, Curr. Psychol., 36, 697-706 (2017) https://doi.org/10.1007/s12144-0169457-8

23. P. Yulianti and F. P. Arifien, Innovative behavior on millennials: Antecedent proactive personality and task conflict with moderating job autonomy, J. Manaj. dan Pemasar. Jasa, 12, 177 (2019) https://doi.org/10.25105/jmpj.v12i2.4358

24. D. E. Purba and J. Paundra, Core self-evaluations and innovative behavior among microentrepreneurs: The mediating effect of proactive personality, Psychol. Res. Urban Soc., 1, 55 (2018) https://doi.org/10.7454/proust.v1i1.30

25. T. S. Bateman and J. M. Crant, The proactive component of organizational behavior, J. Organ. Behav., 14, 103-118 (1993) https://doi.org/10.1002/job.4030140202

26. J. M. Crant and K. Jiang, Proactive personality: A twenty-year review, in Proactivity at Work: Making Things Happen in Organizations, S. Parker and U. Bindl, 193-225 (Routledge, New York, 2017)

27. C. Wu and W. Li, Individual differences in proactivity: a developmental perspective, in Proactivity at Work: Making Things Happen in Organizations, S. K. Parker and U. K. Bindl, 226-257 (Routledge, New York, 2017)

28. O. Janssen, Job demands, perceptions of effort-reward fairness and innovative work behaviour, J. Occup. Organ. Psychol., 73, 287-302 (2000) https://doi.org/10.1348/096317900167038

29. S. G. Scott and R. A. Bruce, Determinants of innovative behavior: A path model of individual innovation in the workplace, Acad. Manag. J., 37, 580-607 (1994) https://doi.org/10.5465/256701

30. R. M. Kanter, Three tiers for innovation research, Communic. Res., 15, 509-523 (1988) https://doi.org/10.1177/016344300022005001

31. S. N. Kostromina and N. V. Grishina, The dynamic personality: 'Continuity amid change,' Psychol. Russ. State Art, 12, 34-45 (2019) https://doi.org/10.11621/pir.2019.0203

32. A. Bandura, A social cognitive theory of personality, Handb. Personal. Theory Res., 2, 154-196 (1999) https://doi.org/10.1016/0749-5978(91)90022-L

33. W. D. Li, D. Fay, M. Frese, P. D. Harms, and X. Y. Gao, Reciprocal relationship between proactive personality and work characteristics: A latent change score approach, J. Appl. Psychol., 99, 948-965 (2014) https://doi.org/10.1037/a0036169

34. E. G. Kirby, S. L. Kirby, and M. A. Lewis, A study of the effectiveness of training proactive thinking, J. Appl. Soc. Psychol., 32, 1538-1549 (2002), https://doi.org/10.1111/j.1559-1816.2002.tb01451.x

35. G. Messmann and R. H. Mulder, Innovative work behaviour in vocational colleges: Understanding how and why innovations are developed, Vocat. Learn., 4, 63-84 (2011) https://doi.org/10.1007/s12186-010-9049-y

36. S. E. Seibert, M. L. Kraimer, and J. M. Crant, What do proactive people do? A longitudinal model linking proactive personality and career success, Pers. Psychol., 54, 845-874 (2001) https://doi.org/10.1111/j.1744-6570.2001.tb00234.x

37. R. E. Maunder, M. Cunliffe, J. Galvin, S. Mjali, and J. Rogers, Listening to student voices: Student researchers exploring undergraduate experiences of university 
transition, High. Educ., 66, 139-152 (2013) https://doi.org/10.1007/s10734-012-95953

38. A. Etikariena and H. Muluk, Correlation between organizational memory and innovative work behavior, Makara Hum. Behav. Stud. Asia, 18, 77 (2014) https://doi.org/10.7454/mssh.v18i2.3463

39. A. Nabilah, Hubungan antara kepribadian proaktif dan efikasi diri dalam keputusan karir pada mahasiswa, Universitas Indonesia (2015)

40. P. M. Podsakoff, S. B. MacKenzie, J. Y. Lee, and N. P. Podsakoff, Common method biases in behavioral research: A critical review of the literature and recommended remedies, J. Appl. Psychol., 88, 879-903 (2003), https://doi.org/10.1037/00219010.88.5.879

41. A. W. Meade and S. B. Craig, Identifying careless responses in survey data, Psychol. Methods, 17, 437-455 (2012) https://doi.org/10.1037/a0028085

42. R. M. Kaplan and Saccuzzo, Psychological testing Principles, Application, and Issues, 7th ed. (Thomson Wadsworth, Belmont, 2009)

43. J. C. Nunnally and I. H. Bernstein, Psychometric Theory, 3nd ed. (McGraw-Hill Education, New York, 1994)

44. K. Józsa and G. A. Morgan, Reversed items in likert scales: Filtering out invalid responders, J. Psychol. Educ. Res., 25, 7-25 (2017)

45. J. Cohen, Statistical power analysis for the behavioral sciences, 2nd ed. (Lawrence Erlbaum Associates, New Jersey, 1988)

46. J. Pallant, SPSS Survival Manual: A Step by Step Guide to Data Analysis Using IBM SPSS, 6th ed. (McGraw-Hill Education, Maidenhead, 2016) 